\title{
Serological study of TORCH complex in pregnant women with an obstetric history in Mosul city, Iraq
}

\author{
Mohammed T. Mahmood ${ }^{1}$ and Hasan Faisal Hussein Kahya ${ }^{2, *}$ \\ ${ }^{1}$ Department of Basic Sciences, College of Nursing, University of Mosul, Iraq; \\ ${ }^{2}$ Department of Biology, College of Education for Pure Sciences, University of Mosul, Iraq.
}

\begin{abstract}
Abortion is considered as one of the major problems in women which can lead to termination of fertility. Most abortion cases are directly linked with TORCH complex or congenital infections including bacterial, viral, and protozoal infections. Here, we collected 109 serum samples from pregnant women (study group) and 64 nonpregnant women (control group). The samples were directly examined for the presence of antiTORCH-IgM and anti-TORCH-IgG antibodies against TORCH complex using enzyme-linked immunosorbent assay (ELISA) technique. Out of 109 pregnant in the study group, 51 cases (46.8\%) were seropositive for IgG antibodies and 33 cases (30.25\%) were seropositive for IgM antibodies. Non-pregnant had lower rates of TORCH complex seropositive. The majority of seropositive cases in the study group were between ages of 24-29 years. The highest rates of IgG seropositive for Toxoplasma were found in rural areas. The IgG seroprevalence rate of TORCH was highest in second trimester of pregnancy while the maximum rate of abortion was found to be $64 \%$ in the first trimester of pregnancy.
\end{abstract}

KEYWORDS: TORCH complex, toxoplasmaIgM, obstetric history, congenital infections.

\section{INTRODUCTION}

Abortion is an expulsion of the embryo before the $6^{\text {th }}$ month of gestation [1]. Spontaneous abortion

\footnotetext{
*Corresponding author: dr.hasankahya@uomosul.edu.iq
}

is the term for the termination of pregnancy which occurs due to the lack of deliberate examining. However, induced abortion is a term that refers to the termination of pregnancy which occurs during a deliberate intervention. This usually occurs after the age of 30-35 years, and might lead to potential fertility decrease and thus, increase in the rate of spontaneous abortion [2,3]. The bacterial, viral and protozoal infections can cause predominant infections in fetus or neonate. These infections might cause miscarriage and lead to congenital anomalies of the fetus. On the other hand, other infections might be associated with the morbidity of neonate. However, it has been reported that most of the maternal infections might not lead to fetal infections $[4,5]$. During pregnancy, the first trimester is the vital period because most of the complications such as bleeding of vagina and pain occur in this period. These complications might lead to severe apprehensions in pregnant women [3].

TORCH complex or congenital infections are known as dangerous infections of fetus. These infections are caused by Toxoplasma gondii, some viruses such as HIV, syphilis, Rubella virus, Cytomegalovirus, and Herpes viruses [6, 7]. The prevalence of TORCH infections is dependent on the different geographical areas [8]. Furthermore, these infections usually start with no symptoms or are asymptomatic. Therefore, the diagnostic procedure of TORCH infections is problematic. The diagnosis of acute TORCH infections in pregnant women relies on seroconversion of paired sera or by checking of anti-TORCH-IgM 
profile [8, 9]. Enzyme-linked immunosorbent assay (ELISA) is widely used for testing the prevalence of TORCH antibodies as it is a very sensitive and specific method $[10,11]$.

TORCH test detects the antibody levels of specific groups of infections in patients' blood $[12,13]$. The TORCH panel usually measures anti-TORCH-IgG levels in post-exposure to the TORCH infections. This means that the infections are at the late stage of infection. Otherwise, antiTORCH-IgM detection might be difficult in the early stage of infection, and might lead to false negative and positive results $[14,15]$.

Here, we aimed to investigate the TORCH infections in pregnant and non-pregnant women with and without obstetric history using conventional ELISA method for Seroprevalence of anti-TORCH-IgG and IgM.

\section{PATIENTS AND METHODS}

The study was done on pregnant patients with an obstetric history who had visited Mother and Child Health Center Laboratory in Mosul, for routine check and examination from June 2020 to July 2021. The study was conducted after getting approval from Iraqi Medical institutions and Health Ministry. $5 \mathrm{ml}$ of blood samples was aspirated from 109 pregnant women aged between 18 to 40 years while 64 non pregnant women served as the control group. Samples were grouped into two, namely urban and rural areas that belonged to different geographical regions in Nineveh province. The samples were then centrifuged to separate serum samples from blood. TORCH serology test was done using a conventional enzyme-linked immunoassay ELISA to determine anti-TORCH-IgM and anti-TORCHIgG antibodies (BioCheck, Foster City). The test was performed according to the manufacturer's instructions. The collected data were then interpreted as seropositive or seronegative based on the presence of antibodies. The positive TORCH-IgG and TORCH-IgM were then linked with gestational age of pregnancy, abortion history, and residency of patients.

\section{Ethics approval}

This study was approved by the Iraqi Medical institutions and Medical Hospitals. Consent from all the patients and healthy controls for collection of sera samples was obtained to conduct this study. The identity of all patients was kept confidential as requested.

\section{RESULTS AND DISCUSSION}

Anti-TORCH-IgG and anti-TORCH-IgM antibody detection was carried out on 109 pregnant women and 64 non-pregnant women using ELISA assay. Table 1 and Figure 1 show sero-positivity of TORCH antibodies in study group and control group. As can be seen from Table 1, out of 109 pregnant women, 51 cases (46\%) were positive to anti-TORCH-IgG. However, 18 cases (28.13\%) of control group were positive to anti-TORCH-IgG. With regard to anti-TORCH-IgM levels, it was found that 33 cases (30.25\%) from study group were positive to TORCH-IgM, while only 5 cases (7.81\%) from control group were positive. On the other hand, 20 (18.3\%) pregnant women were negative to TORCH-IgG and TORCH-IgM (Table 1, Figure 1). These results reflect the diversity of immune responses in pregnant women. Primary stage of TORCH infections in pregnant women might lead to diverse outcomes. This infection might be asymptomatic and thus lead to misdiagnosis in clinical cases [16, 17].

The results revealed that among 109 pregnant women with bad obstetric history, seroprevalence of Toxoplasma IgG (31.2\%) was higher than other TORCH agents. This can be interpreted as chronic infection [18]. The level of anti-toxoplasma antibodies in this study is relatively lower than other studies performed in Iraq. For example, in a study reported by Al-Jubori [19] in Kirkuk antitoxoplasma antibodies were found to be $93.22 \%$ and $61.02 \%$ for pregnant and non-pregnant women, respectively. In another study done by Al-Griari [20] in Diyala, it was found that the rate of seropositivity among pregnant women was $70.4 \%$. Similarly, another study reported that anti-toxoplasma antibodies were $63 \%$ in pregnant women in Mosul city; the decrease in the prevalence rates in these studies might be due to very large sample size [21]. The diversity of sero-positivity varies depending upon different circumstances such as obstetric history, healthcare institutions, educational levels of women, and how far women know about the infections during pregnancy [22]. 
Table 1. Distribution of seropositive TORCH antibodies in relation to age.

\begin{tabular}{|c|c|c|c|c|c|c|}
\hline \multirow{3}{*}{ Age in years } & \multicolumn{6}{|c|}{ Seropositive TORCH antibodies } \\
\hline & \multicolumn{2}{|c|}{$\operatorname{IgM(+)~and~IgG(-)~}$} & \multicolumn{2}{|c|}{$\operatorname{IgM}(-)$ and $\operatorname{IgG}(+)$} & \multicolumn{2}{|c|}{$\operatorname{IgM}(+)$ and $\operatorname{IgG}(+)$} \\
\hline & No. & $\%$ & No. & $\%$ & No. & $\%$ \\
\hline $\begin{array}{c}\text { Toxoplasma } \\
18-23 \\
24-29 \\
30-35 \\
36-40 \\
\end{array}$ & $\begin{array}{l}1 \\
7 \\
2 \\
1\end{array}$ & $\begin{array}{c}3.0 \\
21.2 \\
6.1 \\
3.0 \\
\end{array}$ & $\begin{array}{l}11 \\
18 \\
0.0 \\
0.0 \\
\end{array}$ & $\begin{array}{c}21.3 \\
40.4 \\
0.0 \\
0.0 \\
\end{array}$ & $\begin{array}{c}1 \\
2 \\
0.0 \\
0.0 \\
\end{array}$ & $\begin{array}{l}20 \\
40 \\
0.0 \\
0.0 \\
\end{array}$ \\
\hline Total & 11 & 33.3 & 29 & 61.7 & 3 & 60 \\
\hline $\begin{array}{c}\text { Rubella } \\
18-23 \\
24-29 \\
30-35 \\
36-40\end{array}$ & $\begin{array}{c}0.0 \\
2 \\
1 \\
0.0\end{array}$ & $\begin{array}{l}0.0 \\
6.1 \\
3.0 \\
0.0\end{array}$ & $\begin{array}{c}2 \\
5 \\
1 \\
0.0\end{array}$ & $\begin{array}{l}3.9 \\
9.8 \\
2.0 \\
0.0\end{array}$ & $\begin{array}{l}0.0 \\
0.0 \\
0.0 \\
0.0\end{array}$ & $\begin{array}{l}0.0 \\
0.0 \\
0.0 \\
0.0\end{array}$ \\
\hline Total & 3 & 9.1 & 8 & 15.7 & 0.0 & 0.0 \\
\hline $\begin{array}{l}\text { CMV } \\
18-23 \\
24-29 \\
30-35 \\
36-40 \\
\end{array}$ & $\begin{array}{c}6 \\
9 \\
2 \\
0.0 \\
\end{array}$ & $\begin{array}{c}18.2 \\
27.2 \\
6.1 \\
0.0 \\
\end{array}$ & $\begin{array}{c}3 \\
4 \\
1 \\
0.0 \\
\end{array}$ & $\begin{array}{l}5.9 \\
7.8 \\
2.0 \\
0.0 \\
\end{array}$ & $\begin{array}{c}0.0 \\
2 \\
0.0 \\
0.0\end{array}$ & $\begin{array}{l}0.0 \\
40 \\
0.0 \\
0.0\end{array}$ \\
\hline Total & 17 & 51.5 & 8 & 15.7 & 2 & 40 \\
\hline $\begin{array}{l}\text { HSV } \\
18-23 \\
24-29 \\
30-35 \\
36-40 \\
\end{array}$ & $\begin{array}{c}1 \\
1 \\
0.0 \\
0.0 \\
\end{array}$ & $\begin{array}{c}3.05 \\
3.05 \\
0.0 \\
0.0 \\
\end{array}$ & $\begin{array}{c}2 \\
4 \\
0.0 \\
0.0 \\
\end{array}$ & $\begin{array}{l}3.9 \\
7.8 \\
0.0 \\
0.0 \\
\end{array}$ & $\begin{array}{l}0.0 \\
0.0 \\
0.0 \\
0.0 \\
\end{array}$ & $\begin{array}{l}0.0 \\
0.0 \\
0.0 \\
0.0\end{array}$ \\
\hline Total & 2 & 6.1 & 6 & 11.7 & 0.0 & 0.0 \\
\hline Total No./\% & 33 & 100 & 51 & 100 & 5 & 100 \\
\hline
\end{tabular}

CMV, Cytomegalovirus; HSV, Herpes simplex virus.

Considering the linkage between the groups' age and the distribution of seropositive TORCH complex, it was found that most of the seropositive cases in the study group were in the age range of 24-29 years (Table 1). Furthermore, TORCH-IgG level was high in the age group 2429 years when compared with the age group 3640 years. This shows that TORCH infections were predominant in the sexually active age groups. However, it was reported that CMV-IgM antibodies (27.2\%) was higher than CMV-IgG antibodies (7.8\%). It also was observed that toxoplasma-IgG antibodies were the highest in the age group 24-29 years $(40.4 \%)$. High risk of primary toxoplasmosis in young pregnant women was observed (Table 2). Our results are in line with the study done by Al-Taie [13], who reported that the rate of toxoplasma-IgG in the age group 21-30 years was relatively higher than in the age group 21-30 (57\%). Similarly, Chitapalli and Padmaja [23] revealed that the lowest rate of specific Toxoplasma-IgG and -IgM was found in the age group 15-20 years, and it increased in an age dependent manner. The results also revealed that 


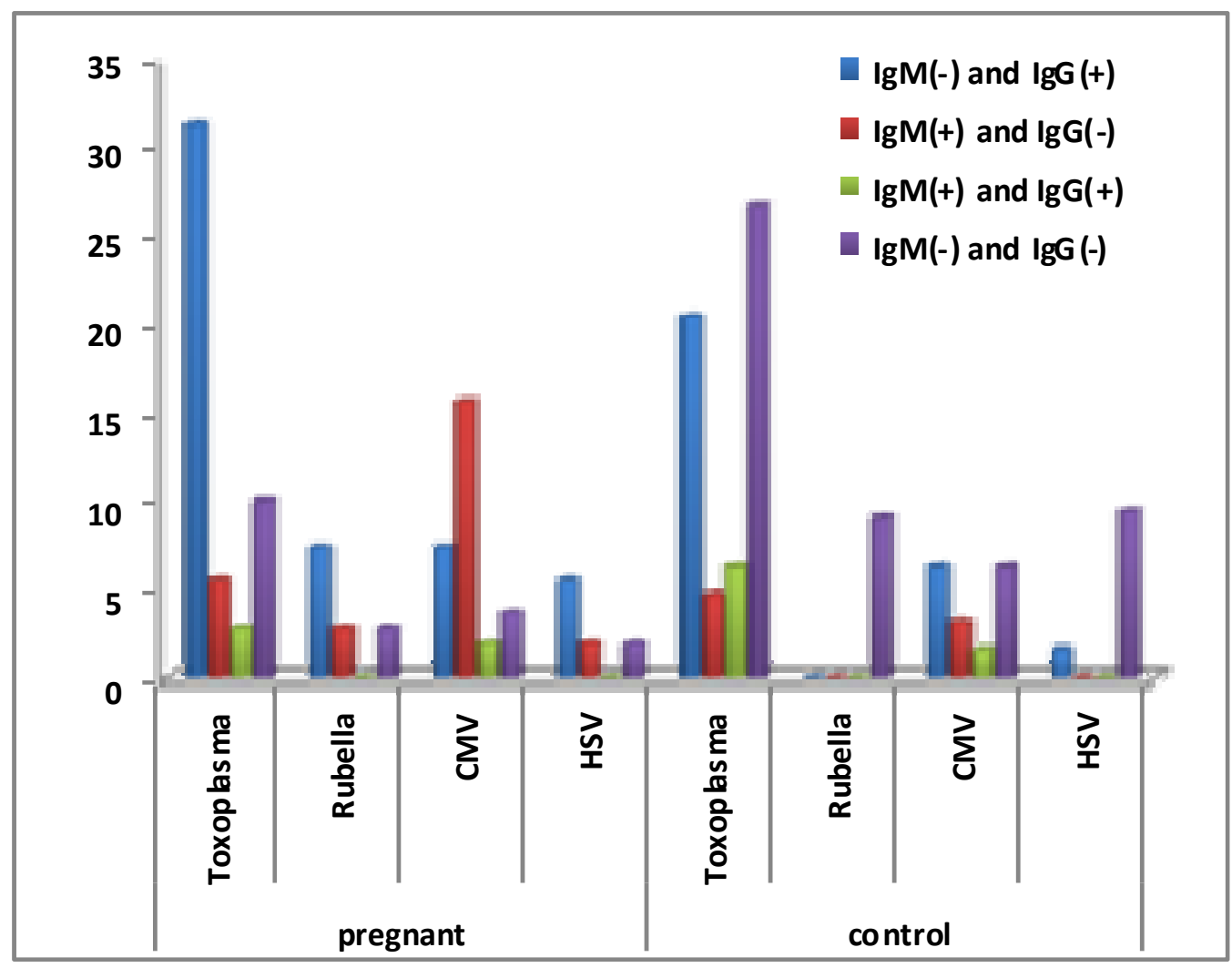

Figure 1. Seroprevalence of TORCH antibodies in pregnant women and control group detected using ELISA assay. CMV, Cytomegalovirus; HSV, Herpes simplex virus.

CMV-IgM rate was $27.2 \%$ in pregnant women, considering that the primary detection of CMVIgM antibodies is a sign of primary infection. Furthermore, it was observed that CMV infections persisted as latent infection in women of childbearing age. Here, it can be concluded that there is an urgent need for early serological evaluation of CMV-IgM during first trimester stage of pregnancy [13].

Table 2 shows the distribution of TORCH-IgG and -IgM in pregnant women in rural and urban areas. As can be seen from the Table, among 29 pregnant women, toxoplasma-IgG was found in 19 women (37.3\%) from rural area, and 10 women (19.6\%) from urban area. It was also found that toxoplasma-IgM levels were less than toxoplasma-IgG in rural and urban areas (Table 2). Diversely, a study done by Mohammed et al. [24], reported that the level of toxoplasma-IgG and -IgM in urban area was higher than rural area. The occurrence of infections in rural and urban areas might be because of close contact with domesticated and agricultural animals such as cats. Furthermore, direct exposure to toxoplasma oocysts occurs by ingestion of the contaminated soil during gardening, or by eating raw and uncooked meat contaminated with cyst. Moreover, it can be noted here that the uneducated women might not be aware of the toxoplasmosis risk factors. As a result, a high rate of infection is? high rates of infections are possible [23].

The results also showed that the highest level of CMV infections during pregnancy was reported in women from rural areas. That means CMV infection is predominant in rural areas. The highest rate of CMV-IgM seropositive was 11 (33.3\%) in pregnant women from rural areas compared to urban areas which was 6 (18.2\%) (Table 2). This infection is considered asymptomatic in adults as it is difficult to be diagnosed clinically. Furthermore, detection of high level of IgM is a sign of early stage of infection [16]. Viral pathogens 
Table 2. Area-wise distribution of TORCH antibodies in pregnant women.

\begin{tabular}{|c|c|c|c|c|c|c|}
\hline \multirow{3}{*}{ Areas/agents } & \multicolumn{6}{|c|}{ Seropositive TORCH antibodies } \\
\hline & \multicolumn{2}{|c|}{$\operatorname{IgM(+)}$ and IgG(-) } & \multicolumn{2}{|c|}{$\operatorname{IgM(-)}$ and IgG(+) } & \multicolumn{2}{|c|}{$\operatorname{IgM}(+)$ and $\operatorname{IgG}(+)$} \\
\hline & No. & $\%$ & No. & $\%$ & No. & $\%$ \\
\hline $\begin{array}{c}\text { Toxoplasma } \\
\text { Urban } \\
\text { Rural } \\
\end{array}$ & $\begin{array}{l}2 \\
9 \\
\end{array}$ & $\begin{array}{c}6.1 \\
27.2 \\
\end{array}$ & $\begin{array}{l}10 \\
19 \\
\end{array}$ & $\begin{array}{l}19.6 \\
37.3 \\
\end{array}$ & $\begin{array}{l}1 \\
2 \\
\end{array}$ & $\begin{array}{l}20 \\
40 \\
\end{array}$ \\
\hline Total & 11 & 33.3 & 29 & 56.9 & 3 & 60 \\
\hline $\begin{array}{c}\text { Rubella } \\
\text { Urban } \\
\text { Rural } \\
\end{array}$ & $\begin{array}{l}2 \\
1 \\
\end{array}$ & $\begin{array}{l}6.1 \\
3.0 \\
\end{array}$ & $\begin{array}{l}6 \\
2 \\
\end{array}$ & $\begin{array}{c}11.8 \\
3.9 \\
\end{array}$ & $\begin{array}{l}0.0 \\
0.0 \\
\end{array}$ & $\begin{array}{l}0.0 \\
0.0 \\
\end{array}$ \\
\hline Total & 3 & 9.1 & 8 & 15.7 & 0.0 & 0.0 \\
\hline $\begin{array}{l}\text { CMV } \\
\text { Urban } \\
\text { Rural } \\
\end{array}$ & $\begin{array}{c}6 \\
11 \\
\end{array}$ & $\begin{array}{l}18.2 \\
33.3 \\
\end{array}$ & $\begin{array}{l}3 \\
5\end{array}$ & $\begin{array}{l}5.9 \\
9.8 \\
\end{array}$ & $\begin{array}{c}0.0 \\
2 \\
\end{array}$ & $\begin{array}{c}0.0 \\
40 \\
\end{array}$ \\
\hline Total & 17 & 51.5 & 8 & 15.7 & 2 & 40 \\
\hline $\begin{array}{l}\text { HSV } \\
\text { Urban } \\
\text { Rural }\end{array}$ & $\begin{array}{c}2 \\
0.0\end{array}$ & $\begin{array}{l}6.1 \\
0.0\end{array}$ & $\begin{array}{l}4 \\
2\end{array}$ & $\begin{array}{l}7.8 \\
3.9\end{array}$ & $\begin{array}{l}0.0 \\
0.0\end{array}$ & $\begin{array}{l}0.0 \\
0.0\end{array}$ \\
\hline Total & 2 & 6.1 & 6 & 11.7 & 0.0 & 0.0 \\
\hline Total No./\% & 33 & 100 & 51 & 100 & 5 & 100 \\
\hline
\end{tabular}

CMV, Cytomegalovirus; HSV, Herpes simplex virus.

in primary maternal infections usually cause viremia which might lead to infection the placenta. However, HSV infections start from genital tract and spread to the fetal membrane causing fetal infections [25].

The incidence of TORCH infection in the first, second and third trimester noted to evaluate the development of TORCH-IgG and -IgM levels in pregnant women (Table 3). As can be seen from Table 3, the level of seropositive CMV-IgM antibodies was highest in the first trimester, 11 (33.3\%). Similarly, Toxoplasma gondii IgM level was found to be 9 (27.2\%), while in second trimester, the seropositive IgM was relatively lower than first trimester. The first trimester is usually the most dangerous stage for pregnant women and they are most likely to catch TORCH infection [16]. The consequences occurring in the first trimester are more likely to be abortion, still birth or severe disease of fetus [26]. On the other hand, toxoplasma-IgG titer was found to be higher than toxoplasma-IgM (Table 3). However, Mohammed et al. [24] reported that second trimester is more dangerous than first trimester of pregnancy. In general, congenital toxoplasmosis is most severe when the pregnant women are infected in the first trimester [27].

The relationship of TORCH seroprevalence with the abortion history and gestational age was reported in this study. Tables 4 and 5 show the relationship of TORCH complex with the history of abortion in pregnant women, and total abortion cases due to TORCH infection and its relationship with gestational age, respectively. As can be seen from Table 4, the highest rate of seropositive TORCH antibodies was found in sera of pregnant women with no abortion, 61 (68.5\%), followed by women with one abortion, 12 (13.5\%) (Table 4). There is a difference between the number of abortion and the gestational age of abortion that 
Table 3. Seropositivity of TORCH antibodies in relation to gestational age.

\begin{tabular}{|c|c|c|c|c|c|c|}
\hline \multirow{3}{*}{ Gestational age } & \multicolumn{6}{|c|}{ Pattern of antibodies } \\
\hline & \multicolumn{2}{|c|}{$\operatorname{IgM}(+)$ and $\operatorname{IgG}(-)$} & \multicolumn{2}{|c|}{$\operatorname{IgM}(-)$ and $\operatorname{IgG}(+)$} & \multicolumn{2}{|c|}{$\operatorname{IgM}(+)$ and $\operatorname{IgG}(+)$} \\
\hline & No. & $\%$ & No. & $\%$ & No. & $\%$ \\
\hline $\begin{array}{l}\text { Toxoplasma } \\
\text { First trimester } \\
\text { Second trimester } \\
\text { Third trimester }\end{array}$ & $\begin{array}{c}9 \\
2 \\
0.0\end{array}$ & $\begin{array}{c}27.2 \\
6.1 \\
0.0\end{array}$ & $\begin{array}{c}10 \\
15 \\
4\end{array}$ & $\begin{array}{c}19.6 \\
29.45 \\
7.85\end{array}$ & $\begin{array}{c}2 \\
1 \\
0.0\end{array}$ & $\begin{array}{l}40 \\
20 \\
0.0\end{array}$ \\
\hline Total & 11 & 33.3 & 29 & 61.7 & 3 & 60 \\
\hline $\begin{array}{c}\text { Rubella } \\
\text { First trimester } \\
\text { Second trimester } \\
\text { Third trimester } \\
\end{array}$ & $\begin{array}{c}2 \\
1 \\
0.0\end{array}$ & $\begin{array}{l}6.1 \\
3.0 \\
0.0 \\
\end{array}$ & $\begin{array}{l}2 \\
5 \\
1 \\
\end{array}$ & $\begin{array}{l}3.9 \\
9.8 \\
2.0 \\
\end{array}$ & $\begin{array}{l}0.0 \\
0.0 \\
0.0 \\
\end{array}$ & $\begin{array}{l}0.0 \\
0.0 \\
0.0 \\
\end{array}$ \\
\hline Total & 3 & 9.1 & 8 & 17 & 0.0 & 0.0 \\
\hline $\begin{array}{c}\text { CMV } \\
\text { First trimester } \\
\text { Second trimester } \\
\text { Third trimester }\end{array}$ & $\begin{array}{c}11 \\
5 \\
1\end{array}$ & $\begin{array}{c}33.3 \\
18.2 \\
3.2 \\
\end{array}$ & $\begin{array}{l}3 \\
4 \\
1\end{array}$ & $\begin{array}{l}5.9 \\
7.8 \\
2.0\end{array}$ & $\begin{array}{c}2 \\
0.0 \\
0.0\end{array}$ & $\begin{array}{l}40 \\
0.0 \\
0.0\end{array}$ \\
\hline Total & 17 & 51.5 & 8 & 17 & 2 & 40 \\
\hline $\begin{array}{c}\text { HSV } \\
\text { First trimester } \\
\text { Second trimester } \\
\text { Third trimester }\end{array}$ & $\begin{array}{c}2 \\
0.0 \\
0.0\end{array}$ & $\begin{array}{l}6.1 \\
0.0 \\
0.0\end{array}$ & $\begin{array}{c}2 \\
4 \\
0.0\end{array}$ & $\begin{array}{l}3.9 \\
7.8 \\
0.0 \\
\end{array}$ & $\begin{array}{l}0.0 \\
0.0 \\
0.0\end{array}$ & $\begin{array}{l}0.0 \\
0.0 \\
0.0\end{array}$ \\
\hline Total & 2 & 6.1 & 6 & 11.7 & 0.0 & 0.0 \\
\hline Total No./\% & 33 & 100 & 51 & 100 & 5 & 100 \\
\hline
\end{tabular}

CMV, Cytomegalovirus; HSV, Herpes simplex virus.

Table 4. Relation of TORCH infection with history of abortion in pregnant women.

\begin{tabular}{|c|c|c|c|c|c|c|c|c|c|}
\hline \multirow{2}{*}{ Total seropositive cases } & \multicolumn{9}{|c|}{ History of abortion } \\
\cline { 3 - 11 } & \multicolumn{2}{|c|}{} & \multicolumn{2}{|c|}{ No abortion } & \multicolumn{2}{c|}{ One time } & \multicolumn{2}{c|}{ Two time } & \multicolumn{3}{c|}{ Three or more } \\
\hline No. & $\%$ & No. & $\%$ & No. & $\%$ & No. & $\%$ & No. & $\%$ \\
\hline 89 & 100 & 61 & 68.5 & 12 & 13.5 & 9 & 10.1 & 7 & 7.9 \\
\hline
\end{tabular}

Table 5. Total abortion cases due to TORCH infection according to gestational age.

\begin{tabular}{|c|c|c|c|c|c|c|c|}
\hline \multirow{2}{*}{ Total abortion cases } & \multicolumn{4}{|c|}{ Gestational age } \\
\cline { 3 - 8 } & \multicolumn{2}{|c|}{ First trimester } & \multicolumn{2}{c|}{ Second trimester } & \multicolumn{2}{c|}{ Third trimester } \\
\hline No. & $\%$ & No. & $\%$ & No. & $\%$ & No. & $\%$ \\
\hline 28 & 100 & 18 & 64.3 & 9 & 32.1 & 1 & 3.6 \\
\hline
\end{tabular}


might be caused by previous infections in different pregnancy trimesters and immunological state of the pregnant woman [28]. The highest number of abortion was reported in the first trimester 18 (64.3\%), followed by the second and third trimester - $9(32.1 \%)$ and 1 (3.6\%), respectively (Table 5). The decrease in abortion in the second and third trimester might be an indication of antiTORCH maternal immunity that might prevent the abortion caused by TORCH infections [29].

\section{CONCLUSION}

Based on the results in this manuscript, it can be concluded that seroprevalence of Toxoplasma IgG in pregnant women was higher than other TORCH agents. Furthermore, the majority of the seropositive cases in the study group was in the age range between 24-29 years. It can also be concluded that CMV infection in the first trimester of pregnancy has a higher incidence in rural areas with higher rate of abortion.

\section{ACKNOWLEDGEMENTS}

This study was supported by the Department of Biology, College of Education for Pure Sciences, University of Mosul. Many thanks to all participants and patients for donating their blood samples. Great thanks to Central Laboratories/Nenawa Health Office and to the doctors and nurses who were supportive in accomplishing this study.

\section{AUTHORS' CONTRIBUTIONS}

M. T. M. designed and performed the experiments. M. T. M. and H. F. H. K. wrote the manuscript. All authors discussed the results. H. F. H. K. revised the final copy of the manuscript.

\section{CONFLICT OF INTEREST STATEMENT}

The author declares no conflicts of interest.

\section{REFERENCES}

1. AL-Rubayee, M. G. J. and AL-Hamdani, I. T. A. 2010, Iraqi J. Comm. Med., 3, 208.

2. Leveno, K. J., Cunningham, F. G., Alexander, J. M., Bloom, S. L., Casey, B. M., Dashe, J. S., Sheffield, J. S. and Roberts, S. W. 2007, Williams Manual of Obstetrics Pregnancy Complications, 22 Edition, Mc grew hill, Texas.
3. Sabina, l., Shanti, S., Sita, P., Manisha, C. and Basudev, B. 2016, J. Nob. Med. Coll., 5, 17.

4. Sadik, M. S., Fatima, H., Jamil, K. and Patil, C. 2012, Biol. Med., 4, 95.

5. Langford, K. S. 2002, Cur. Obst. Gynecol., 12, 125.

6. Namrata, S., Manju, L., Garima, M. and Priya. 2015, Int. J. Biol. Med. Res., 6, 5158.

7. Navolan, D. B., Ciohat, M. L., Tigla, E. A., Vasies, D. and Dumitrascu, V. 2012, TMJ., 62, 15.

8. Kumari, N., Morris, N. and Dutta, R. 2011, J. Health Popul. Nutr., 29, 77.

9. Saraswathy, T. S., Az-Ulhusna, A., Asshikin, R. N., Suriani, S. and Zainah, S. 2011, Southeast Asian J. Trop. Med. Pub. Heal., 42, 320.

10. Thapliyal, N., Shukla, P. K., Kumar, B., Upadhyay, S. and Jain, G. 2005, Indian J. Pathol. Microbiol., 48, 551.

11. Numan, O., Vural, F., Aka, N., Alpay, M. and Coskun, A. D. 2015, North Clin. Istanb., 2, 203.

12. Jawetz, E., Melnick, J. L., Adelberg, E. A. and Brooks, G. F. 2004, Herpesviruses Chapter 33. Jawetz, Melnick and Adelberg Medical Microbiology. 23 ${ }^{\text {rd }}$ Ed., Lange Medical Books, McGraw Hill, USA.

13. Al-Taie, A. A. D. 2010, Tikrit J. Pure Sci., 15, 193.

14. Madrid, L., Varo, R., Sitoe, A. and Bassat, Q. 2016, Expert Rev. Anti-Infect. Ther., 14, 845.

15. Ursu, R. G., Costin, D., Iancu, L. S. and Nemescu, D. 2015, E-Health Bioeng. Conf., 1.

16. Rorman, E., Zamir, C. S., Rilkis, I. and Ben-David, H. 2006, J. Reprod. Toxicol., 21, 458.

17. Lin, M., Chen, T., Kuo, T., Tseng, C. and Tseng, C. 2002, J. Clin. Microbiol., 38, 4121.

18. Stillwaggon, E., Carrier, C. S., Sautter, M. and Macleod, R. 2011, PLoS Negl. Trop. Dis., 5, e1333.

19. Al-Jubori, A. M. 2005, Serological study of Toxoplasmosis in Kirkuk Province. M.Sc. Thesis, College of Health and Medical Technology, Foundation of Technical Education, Baghdad University, Iraq. 
20. Al-Griari, A. J. A. 2007, A seroepidemiological study of toxoplasmosis in Diyala province/ Iraq. M.Sc. Thesis, College of Education, Diyala University, Iraq.

21. Abdulla, B. A. and Omer, F. H. 2007, Tikrit J. Pure Sci., 12, 39.

22. Singh, S. 2003, Indian J. Med. Microbiol., 212, 69.

23. Chintapalli, S. and Padmaja, J. I. 2013, Trop. Parasitol., 3, 62.

24. Mohammad, M., Ahmed, S. and Hussain, A. 2012, Int. J. Med. Sci., 4, 55.

25. Surpam, R. B., Kmlakar, U. P., Khadse, R. K.,
Qazi, M. S. and Jalgaonkar, S. V. 2006, J. Obstet. Gynaecol. India, 56, 41.

26. Pandolfi, E., Chiaradia, G., Moncada, M., Rava, L. and Tozzi, A. E. 2009, Euro. Surveill., 14, 16.

27. Padmavathy, M., Gowri, M., Malini, J., Umapathyavanee, B. L., Navaneeth, B. V., Bhatia, M. and Harle, S. 2013, J. Clin. Biomed. Sci., 3, 62.

28. Kishore, J., Misra, R., Paisal, A. and Pradeep, Y. 2011, J. Infect. Dev. Ctries., 5, 868.

29. Abdul Mohymen, N., Hussien, A. and Hassan, F. K. 2009, Iraqi J. Med. Sci., 7, 40. 